\title{
Nitrogen retention response to the abomasal infusion of amino acids in South African Mutton Merino lambs
}

\author{
A.V. Ferreira ${ }^{\#}$, H.J. van der Merwe and M.D. Fair \\ Department of Animal, Wildlife and Grassland Sciences, University of the Free State, PO Box 339, Bloemfontein 9300, \\ South Africa
}

\begin{abstract}
The nitrogen $(\mathrm{N})$ retention response to the abomasal infusion of amino acids in South African Mutton Merino ram lambs fed a standard finishing diet was investigated. The basal diet consisted of $(\mathrm{g} / \mathrm{kg}$ air dry weight): 300 lucerne, 80 wheat straw, 561.5 maize meal, 35 molasses meal, 10 urea, 5 salt, 7.5 ammonium chloride, 1.0 vitamin/mineral premix and 0.29 taurotec ${ }^{\circledR}$. Twenty-eight lambs ( $c a .38 \mathrm{~kg}$ live weight) were randomly allocated to four treatments consisting of different abomasal infusion rates of an amino acid mixture, formulated to contain essential amino acids in the same ratio as that of the whole empty body. The mixture consisted of $(\mathrm{g} / \mathrm{kg}): 119.7$ arginine, 154.9 histidine, 22.1 isoleucine, 106.5 leucine, 91.5 lysine, 146.9 methionine, 105.6 phenylalanine, 133.8 threonine and 118.7 valine. The mixture was infused at levels of $(\mathrm{g} / \mathrm{d}): 0.00,38.27$, 51.02 or 63.78 . Glycine was used to balance the various mixtures on an iso-nitrogenous basis. Infusion of 51.02 $\mathrm{g} / \mathrm{d}$ of the essential amino acid mixture resulted in a significant increase in $\mathrm{N}$ retention, expressed as a percentage of $\mathrm{N}$ intake, compared to the control group which received the test diet and glycine (Phase 1). The omission of histidine, methionine or threonine from the infusate (Phase 2) had no significant decrease in N retention or plasma amino acid concentrations compared to the infusion of the mixture of nine essential amino acids.
\end{abstract}

Keywords: Essential amino acid, nitrogen retention, sheep

\# Corresponding author. Present address: Department of Animal Sciences, Faculty of Agricultural and Forestry Sciences, University of Stellenbosch, Stellenbosch 7600, South Africa, E-mail: avf@sun.ac.za.

\section{Introduction}

The duodenal supply of amino acids in ruminants originates from microbial-, rumen undegradable and endogenous protein (Cecava et al., 1990). Nimrick et al. (1970) and Schelling et al. (1973) reported an increase in nitrogen $(\mathrm{N})$ retention in sheep in response to abomasal methionine infusion. These findings indicate that tissue amino acid requirements are not met by the supply from rumen microorganisms, and suggest that the efficiency of $\mathrm{N}$ utilization in ruminants could be improved by supplementing the post-ruminal supply of microbial amino acids. The first step in developing such a strategy would be to quantify the amino acid requirement of the host animal (Tao et al., 1974). Amino acid requirements vary according to the physiological state of the animal. Therefore, the response to the post-ruminal infusion of a particular amino acid may vary (Chalupa, 1975). According to Owens \& Bergen (1983) and Storm \& Ørskov (1984), the most limiting amino acids in microbial protein for sheep are methionine, lysine, threonine, histidine and arginine, the relative importance of which may vary according to the physiological function of the animal. Methionine was reported to be the most limiting amino acid in diets containing non-protein-nitrogen as the sole source of N (Schelling \& Hatfield, 1968; Nimrick et al., 1970), in diets containing high levels of urea (Loosli \& Harris, 1945) and in diets that contained only natural proteins (Schelling et al., 1973). Coetzee (1988) found methionine and lysine to be respectively the first and second limiting for wool growth and $\mathrm{N}$ retention in growing lambs. An increase in $\mathrm{N}$ retention in steers and lambs was reported, following post-ruminal infusion of methionine (Loerch \& Oke, 1984). According to Ferreira et al. (1999) the four most limiting essential amino acids (EAA) for optimal whole body protein synthesis, determined by the ideal protein concept, are histidine, methionine, threonine and arginine. However, according to the literature responses to amino acid supplementation can vary considerably between trials. This could be due to the fact that different techniques might have been followed or that all the limiting amino acids might not have been identified and/or supplemented. Erasmus (1992) suggested that the supplementation of a non-degradable protein supplement containing two to five amino acids should give a better response than one containing a single amino acid. With the exception of the study by Young et al. (1981), who 
supplied a combination of all 10 EAA, little information has been reported on multiple amino acid infusions. According to Chen \& Ørskov (1994) the classical approach in investigating amino acid supplementation has been to measure responses to increasing levels of specific amino acids. When the optimum response is obtained, the procedure is repeated for each amino acid until all amino acids have been included. However, Chen \& Ørskov (1994) pointed out that this procedure is invalid since the first limiting amino acid is usually unknown. An alternative approach, suggested by Storm \& Ørskov (1984), was to include a nine EAA supplement, followed by the step-wise omission of amino acids from the mixture. This approach would provide information on the relative importance of each amino acid and was used in the present study to determine if the sequence of limiting EAA coincides with that determined by Ferreira et al. (1999). The aim of this study was, therefore, to determine the $\mathrm{N}$ retention of South African Mutton Merino ram lambs fed a standard finishing diet: (a) with the simultaneous abomasal infusion of nine different EAA at three levels, and (b) the effect of omitting histidine, methionine or threonine from the infusate on $\mathrm{N}$ retention.

\section{Material and Methods}

Twenty eight abomasally fistulated South African Mutton Merino ram lambs (38 $1.77 \mathrm{~kg}$ live weight) were randomly allocated to four groups of seven lambs each (Phase 1 and 2). The finishing diet, fed ad libitum, was described by Loëst et al. (1997) and Loëst et al. (1999), and consisted of (g/kg air dry weight): 300 lucerne, 80 wheat straw, 561.5 maize meal, 35 molasses meal, 10 urea, 5 salt, 7.5 ammonium chloride, 1.0 vitamin-

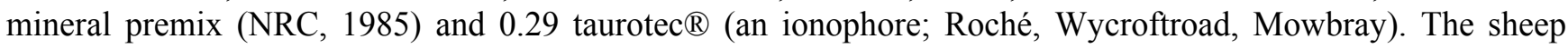
were fed individually in metabolism crates and had free access to water.

The microbial EAA profile in the duodenum of sheep on the same diet was measured by Ferreira et al. (1999). Based on the EAA profile of the whole empty body of sheep (Ferreira et al., 1999), a supplemental EAA mixture was formulated to correct the amino acid imbalances of the microbial protein in the duodenum (Ferreira et al., 1999). Glycine was included in these mixtures at different levels per treatment to ensure that the mixtures were iso-nitrogenous (Mesbah \& Asplund, 1984). In Phase 1 of the trial, the four treatments consisted of the infusion of four different quantities of the supplemental EAA mixture directly into the abomasums of the sheep (Table 1).

Table 1 Quatity of invidual essential amino acids infused daily into the abomasums of the sheep during Phase 1

\begin{tabular}{ccccc}
\hline & \multicolumn{4}{c}{ Predicted growth rate $(\mathrm{g} / \mathrm{d})$} \\
\cline { 2 - 5 } & 200 & 350 & 400 & 450 \\
\cline { 2 - 5 } & 0 & 4.58 & 6.11 & 7.64 \\
Arginine & 0 & 5.93 & 7.97 & 9.88 \\
Histidine & 0 & 0.84 & 1.12 & 1.41 \\
Isoleucine & 0 & 4.08 & 5.44 & 6.80 \\
Leucine & 0 & 3.50 & 4.67 & 5.84 \\
Lysine & 0 & 5.63 & 7.50 & 9.38 \\
Methionine & 0 & 4.04 & 5.39 & 6.74 \\
Phenylalanine & 0 & 5.12 & 6.83 & 8.54 \\
Threonine & 0 & 4.54 & 6.06 & 7.57 \\
Valine & 0 & 38.27 & 51.02 & 63.78 \\
\hline Total EAA $(\mathrm{g} / \mathrm{d})$ & 56.21 & 22.48 & 11.24 & 0 \\
\hline Glycine $(\mathrm{g} / \mathrm{d})$ & & & & \\
\hline
\end{tabular}

In Phase 2 of the trial, the effect was investigated of the omission of histidine, methionine and threonine from the mixture that yielded the highest $\mathrm{N}$ retention $(51.02 \mathrm{~g} / \mathrm{d}$ ) in Phase 1 on $\mathrm{N}$ retention (Table 2). The same lambs as in Phase 1 were used.

The branched chain amino acids (valine, isoleucine and leucine) were dissolved in $100 \mathrm{ml}$ water and $10 \mathrm{ml}$ $6 \mathrm{~N} \mathrm{HCl}$ before the other amino acids were added. The infusate was made up to a maximum of two litres with 
distilled water and the $\mathrm{pH}$ of the final mixture was adjusted with $6 \mathrm{~N} \mathrm{HCl}$ to a $\mathrm{pH}$ of 2.3 (Titgemeyer \& Merchen, 1990).

Table 2 Quantity of individual essential amino acids infused daily into the abomasums of the sheep during Phase 2

\begin{tabular}{ccccc}
\hline & \multicolumn{4}{c}{ Limiting amino acids omitted } \\
\hline & Histidine & Methionine & Threonine & None \\
\cline { 2 - 5 } & \multicolumn{5}{c}{ EAA $(\mathrm{g} / \mathrm{d})$} \\
\hline Arginine & 6.11 & 6.11 & 6.11 & 6.11 \\
Histidine & 0 & 7.97 & 7.97 & 7.97 \\
Isoleucine & 1.12 & 1.12 & 1.12 & 1.12 \\
Leucine & 5.44 & 5.44 & 5.44 & 5.44 \\
Lysine & 4.67 & 4.67 & 4.67 & 4.67 \\
Methionine & 7.50 & 0 & 7.50 & 7.50 \\
Phenylalanine & 5.39 & 5.39 & 5.39 & 5.39 \\
Threonine & 6.83 & 6.83 & 0 & 6.83 \\
Valine & 6.06 & 6.06 & 6.06 & 6.06 \\
\hline Total EAA $(\mathrm{g} / \mathrm{d})$ & 43.12 & 43.52 & 44.19 & 51.02 \\
\hline Glycine $(\mathrm{g} / \mathrm{d})$ & 11.47 & 2.70 & 4.30 & 0 \\
\hline
\end{tabular}

The various amino acid mixtures (Phase 1 and 2) were infused continuously into the abomasum for six days, using a peristaltic pump. The first two days were an adaptation period, and sampling of urine and faeces took place over the subsequent four days (Titgemeyer \& Merchen, 1990). At the end of this period (06:30 on the morning of the 7th day), a jugular blood sample was taken from each lamb (Phase 1 and 2) into heparinized tubes and centrifuged for 20 minutes at 3000 revolutions per min to separate the plasma.

Plasma urea concentrations were determined by spectrophotometry (Fawcett \& Scott, 1960). The crude protein concentrations of the diet, faeces and urine were analysed according to AOAC (1984) methods. Blood plasma amino acid composition was determined with a Beckman system 7300 analyser after $22 \mathrm{~h}$ of acid hydrolysis $(6 \mathrm{~N} \mathrm{HCl})$ at $100{ }^{\circ} \mathrm{C}(\mathrm{AOAC}, 1984)$.

Multiple comparisons of means were performed using Tukey's test after analysis of variance (SAS, 1988 and SAS, 1991).

\section{Results and Discussion}

The effects of different levels of abomasal EAA infusion on $\mathrm{N}$ utilization are presented in Table 3. Daily dry matter intake, $\mathrm{N}$ excretion and $\mathrm{N}$ retention did not differ $(\mathrm{P}>0.05)$ between treatments, suggesting that the $\mathrm{N}$ was used with equal efficiencies. Grey (1969) suggested that $\mathrm{N}$ retention expressed as a percentage of $\mathrm{N}$ intake is the most accurate method of protein evaluation. Expressed on this basis, $\mathrm{N}$ retention as a percentage of $\mathrm{N}$ intake was increased $(\mathrm{P}<0.07)$ by the infusion of $51.024 \mathrm{~g} / \mathrm{d}$ of the EAA mixture (Table 3), compared to the control which received the test diet and glycine. No increase in plasma urea concentration occurred even at the highest level (63.78 g EAA/d) of infusion.

The omission of histidine, methionine or threonine had no effect $(\mathrm{P}>0.05)$ on $\mathrm{N}$ retention or plasma urea concentrations (Table 4) compared to the infusion of the mixture of nine essential amino acids. Several researchers have shown that the omission of histidine, methionine or threonine decreased $\mathrm{N}$ retention (Young et al., 1981; Merchen \& Titgemeyer, 1992). According to the chemical score calculated by Ferreira et al. (1999), methionine was second and threonine the third limiting EAA for growth in South African Mutton Merino lambs on the test diet with an effective rumen protein degradability of $80.2 \%$ (Loëst et al., 1999). The lack of response to the omission of histidine, methionine and threonine in the present study could possibly be explained partly by Titgemeyer \& Merchen's (1990) statement that differences in the genetic growth capacity of animals from the same species to deposit lean tissues will alter estimates of amino acid requirements and must be considered when making comparisons between experiments. Furthermore, the protein status before the trial may influence $\mathrm{N}$ retention and estimates of EAA requirements, because Hovel et al. (1987) found that at the same $\mathrm{N}$ input, $\mathrm{N}$ 
retention was greater after protein depletion than before. The use of different techniques in the determination of the limiting EAA may also have influenced results. It was assumed in calculating the requirements for the ideal protein that the proportions of amino acids made available to the metabolic body pool were the same as those in the small intestine. This will not be the case if the amino acids are not digested or absorbed at the same rate of efficiency. These factors could also have influenced the results and need further investigation.

Table 3 The effect of abomasal essential amino acid supply level on nitrogen metabolism in lambs (mean \pm s.d.)

\begin{tabular}{|c|c|c|c|c|}
\hline & \multicolumn{4}{|c|}{ Essential amino acid supply (g/d) } \\
\hline & 0.00 & 38.27 & 51.03 & 63.78 \\
\hline & \multicolumn{4}{|c|}{ Dry matter intake $(\mathrm{kg} / \mathrm{d})$} \\
\hline & $1.39 \pm 0.45$ & $1.30 \pm 0.51$ & $1.53 \pm 0.16$ & $1.35 \pm 0.26$ \\
\hline & \multicolumn{4}{|c|}{ Nitrogen intake $(\mathrm{g} / \mathrm{d})$} \\
\hline Diet & $37.80 \pm 12.46$ & $35.55 \pm 13.32$ & $41.85 \pm 4.34$ & $36.92 \pm 6.95$ \\
\hline Amino acid infusate & 10.49 & 10.49 & 10.49 & 10.49 \\
\hline \multirow[t]{2}{*}{ Total } & $48.29 \pm 12.71$ & $46.04 \pm 13.81$ & $52.34 \pm 5.10$ & $47.41 \pm 7.01$ \\
\hline & \multicolumn{4}{|c|}{ Nitrogen excretion $(\mathrm{g} / \mathrm{d})$} \\
\hline Faeces & $10.28 \pm 1.60$ & $9.03 \pm 1.45$ & $11.41 \pm 1.33$ & $10.68 \pm 1.71$ \\
\hline Urine & $28.71 \pm 1.70$ & $26.62 \pm 1.58$ & $24.44 \pm 1.39$ & $24.40 \pm 1.50$ \\
\hline \multirow[t]{2}{*}{ Total } & $38.99 \pm 2.80$ & $35.64 \pm 2.67$ & $35.85 \pm 2.10$ & $35.08 \pm 2.54$ \\
\hline & \multicolumn{4}{|c|}{ Nitrogen excretion (\% of N-intake) } \\
\hline Faeces & $21.29 \pm 4.84$ & $19.61 \pm 5.27$ & $21.80 \pm 1.97$ & $22.53 \pm 1.47$ \\
\hline \multirow[t]{7}{*}{ Urine } & $59.46 \pm 7.50$ & $57.81 \pm 16.07$ & $46.69 \pm 6.62$ & $51.46 \pm 6.36$ \\
\hline & \multicolumn{4}{|c|}{ Nitrogen retention $(\mathrm{g} / \mathrm{d})$} \\
\hline & $9.50 \pm 4.83$ & $11.61 \pm 8.01$ & $16.62 \pm 3.69$ & $12.62 \pm 3.75$ \\
\hline & \multicolumn{4}{|c|}{ Nitrogen retention ( $\%$ of $\mathrm{N}$-intake) } \\
\hline & $19.25^{\mathrm{a}} \pm 6.97$ & $22.58^{\mathrm{a}} \pm 12.78$ & $31.51^{\mathrm{b}} \pm 4.83$ & $26.02^{\mathrm{a}} \pm 5.02$ \\
\hline & \multicolumn{4}{|c|}{ Plasma urea concentration $(\mathrm{mg} / 100 \mathrm{ml})$} \\
\hline & $12.05 \pm 2.07$ & $9.89 \pm 2.83$ & $10.85 \pm 1.93$ & $9.39 \pm 1.79$ \\
\hline
\end{tabular}

Plasma concentrations of the EAA examined in Phases 1 and 2 were similar for all treatments (Table 5). According to Young et al. (1981) a drastic increase (accumulation) in the concentration of an amino acid in plasma indicates that the amino acid is no longer limiting. No such trends were observed in the present study. This may be related to a possible increased utilization of the supplement EAA for growth, which was not recorded in the present study.

\section{Conclusions}

Abomasal supplementation of the diet containing a high concentration of rumen degradable protein with $51 \mathrm{~g}$ of the essential amino acid mixture resulted in an increased $\mathrm{N}$ retention in comparison with the control group which received the test diet and glycine in the lambs. The lack of a corresponding response of plasma amino acid concentrations and the lack of a response to the omission of certain amino acids from the infusate precluded the identification of the limiting amino acid. Differences in efficiency of absorption and utilization of amino acids should probably also be considered. 
Table 4 The effect of the omission of individual amino acids from the amino acid mixture on nitrogen metabolism in lambs (mean \pm s.d.)

\begin{tabular}{|c|c|c|c|c|}
\hline & \multicolumn{4}{|c|}{ Limiting amino acid omitted } \\
\hline & None & Histidine & Methionine & Threonine \\
\hline & \multicolumn{4}{|c|}{ Dry matter intake (kg/d) } \\
\hline & $1.26 \pm 0.34$ & $1.47 \pm 0.33$ & $1.37 \pm 0.30$ & $1.54 \pm 0.49$ \\
\hline & \multicolumn{4}{|c|}{ Nitrogen intake $(\mathrm{g} / \mathrm{d})$} \\
\hline Diet & $36.68 \pm 9.89$ & $42.65 \pm 9.66$ & $39.97 \pm 8.83$ & $44.83 \pm 14.11$ \\
\hline Amino acid infusate & 8.39 & 8.39 & 8.39 & 8.39 \\
\hline \multirow[t]{2}{*}{ Total } & $45.07 \pm 10.10$ & $51.04 \pm 11.01$ & $48.36 \pm 9.72$ & $53.22 \pm 14.8$ \\
\hline & \multicolumn{4}{|c|}{ Nitrogen excretion (g/d) } \\
\hline Faeces & $9.19 \pm 1.22$ & $12.13 \pm 1.54$ & $10.99 \pm 1.49$ & $13.06 \pm 1.60$ \\
\hline Urine & $21.91 \pm 1.61$ & $25.23 \pm 1.71$ & $23.16 \pm 1.57$ & $25.54 \pm 1.18$ \\
\hline \multirow[t]{2}{*}{ Total } & $31.09 \pm 2.71$ & $37.36 \pm 2.81$ & $34.15 \pm 266$ & $38.60 \pm 2.75$ \\
\hline & \multicolumn{4}{|c|}{ Nitrogen excretion ( $\%$ of $\mathrm{N}$-intake) } \\
\hline Faeces & $20.38 \pm 2.37$ & $23.67 \pm 2.56$ & $22.73 \pm 2.43$ & $24.54 \pm 3.45$ \\
\hline \multirow[t]{7}{*}{ Urine } & $48.61 \pm 8.30$ & $49.44 \pm 6.70$ & $49.89 \pm 6.17$ & $47.99 \pm 8.66$ \\
\hline & \multicolumn{4}{|c|}{ Nitrogen retention $(\mathrm{g} / \mathrm{d})$} \\
\hline & $14.56 \pm 6.79$ & $13.41 \pm 3.81$ & $14.35 \pm 4.55$ & $15.09 \pm 6.63$ \\
\hline & \multicolumn{4}{|c|}{ Nitrogen retention ( $\%$ of $\mathrm{N}$-intake) } \\
\hline & $31.01 \pm 9.01$ & $26.81 \pm 7.73$ & $29.36 \pm 5.24$ & $27.47 \pm 6.54$ \\
\hline & \multicolumn{4}{|c|}{ Plasma urea concentration $(\mathrm{mg} / 100 \mathrm{ml})$} \\
\hline & $9.54 \pm 2.80$ & $8.44 \pm 1.39$ & $9.50 \pm 2.17$ & $8.72 \pm 1.11$ \\
\hline
\end{tabular}

Table 5 Mean ( \pm s.d.) amino acid concentrations in blood plasma of the lambs (g/100 g protein)

\begin{tabular}{ccc}
\hline Amino acid & Phase 1 & Phase 2 \\
\hline Arginine & $4.12 \pm 1.46$ & $2.27 \pm 0.23$ \\
Histidine & $7.79 \pm 2.16$ & $7.94 \pm 1.02$ \\
Leucine & $29.46 \pm 0.74$ & $27.91 \pm 0.78$ \\
Lysine & $9.81 \pm 0.34$ & $9.48 \pm 0.52$ \\
Methionine & $1.55 \pm 0.10$ & $1.43 \pm 0.14$ \\
Phenylalanine & $11.40 \pm 0.39$ & $11.30 \pm 0.26$ \\
Valine & $9.06 \pm 0.25$ & $9.11 \pm 0.20$ \\
\hline
\end{tabular}

\section{Acknowledgements}

The assistance of J.G. van der Walt with duodenal fistulation of experimental animals is gratefully acknowledged. 


\section{References}

AOAC, 1984. Official methods of analysis (14th ed.). Association of Official Analytical Chemists, Arlington, Virginia, USA.

Cecava, M.J., Merchen, N.R., Berger, L.L. \& Fahey, G.C., 1990. Intestinal supply of amino acids in sheep fed alkaline hydrogen peroxide treated wheat straw-based diets supplemented with soybean meal or combinations of corn gluten meal and blood meal. J. Anim. Sci. 68, 467-477.

Chalupa, W., 1975. Rumen bypass and protection of proteins and amino acids. J. Dairy Sci. 58, 1198-1218.

Chen, X.B. \& Ørskov, E.R., 1994. Amino acid nutrition in sheep. Ch. 13 In: Amino acids in farm animal nutrition. Ed. D'Mello, J.P.F. Guildford, UK.

Coetzee, J., 1988. Chemiese metodes om die benutting van laegraadse ruvoer en sintetiese aminosure deur wolskape te verbeter. PhD-Agric. tesis, Universiteit Stellenbosch.

Erasmus, L.J., 1992. Nuwe konsepte in die proteïenvoeding van herkouers 3. Toepassing van die RDP:UDP sisteem vir melkkoeie. Afma Matrix, 1, 14-17.

Fawcett, J.K. \& Scott, J.E., 1960. A rapid and precise method for the determination of urea. J. Clin. Path. 13, 156.

Ferreira, A.V., Van der Merwe, H.J. \& Loëst, C.A., 1999. Amino acid requirements of South African Mutton Merino lambs. 3). Duodenal and whole empty body essential amino acid profile. S. Afr. J. Anim. Sci. 29, 40-47.

Grey, J.H., 1969. Evaluasie van proteïen. Hand. S. Afr. Ver. Diereprod. 8, 35-39.

Hovel, F.D.DeB., Ørskov, E.R., Kyle, D.J. \& MacLeod, N.A., 1987. Undernutrition in sheep - nitrogen repletion by N-depleted sheep. Br. J. Nutr. 57, 77-88.

Loerch, S.C. \& Oke, B., 1984. Effect of supplemental rumen protected lysine and methionine on steer and lamb performance and N-balance. J. Anim. Sci. 59, 404 (abst. 630).

Loëst, C.A., Ferreira, A.V., Van der Merwe, H.J. \& Fair, M.D., 1997. Chemical and essential amino acid composition of South African Mutton Merino lamb carcasses. S. Afr. J. Anim. Sci. 27, 7-12.

Loëst, C.A., Ferreira, A.V., Van der Merwe, H.J. \& Fair, M.D., 1999. Amino acid requirements of South African Mutton Merino lambs. 1). Duodenal and carcass essential amino acid profile. S. Afr. J. Anim. Sci. 29, 15-26.

Loosli, J.K. \& Harris, L.E., 1945. Methionine increases the value of urea for lambs. J. Anim. Sci. 4, 435-437.

Merchen, N.R. \& Titgemeyer, E.C., 1992. Manipulation of amino acid supply to the growing ruminant. J. Anim. Sci. 70, 3238-3247.

Mesbah, M.M. \& Asplund, J.M., 1984. The influence of level of valine on nitrogen status and plasma free amino acid levels in infused sheep. J. Nutr. 114, 1363-1369.

Nimrick, K., Hatfield, E.D., Kaminski, J. \& Owens, F.N., 1970. Qualitative assessment of supplemental amino acid needs for growing lambs fed urea as the sole nitrogen source. J. Nutr. 100, 1293-1300.

NRC, 1985. Nutrient Requirements of Sheep. (6th ed.). National Academy Press, Washington, D.C.

Owens, F.N. \& Bergen, W.G., 1983. Nitrogen metabolism of ruminant animals: Historical perspective: current understanding and future implications. J. Anim. Sci. 57, 498-518.

SAS, 1988. SAS Procedures Guide, Release 6.03 ed. SAS Institute Inc., Cary, N.C.

SAS, 1991. SAS Systems for Regression, Second ed. SAS Institute Inc., Cary, N.C.

Schelling, G.T. \& Hatfield, E.E., 1968. Effect of abomasally infused nitrogen sources on nitrogen retention of growing lambs. J. Nutr. 96, 319-326.

Schelling, G.T., Chandler, J.E. \& Scott, G.C., 1973. Postruminal supplemental methionine infusion to sheep fed high quality diets. J. Anim. Sci. 37, 1034-1039.

Storm, E. \& Ørskov, E.R., 1984. The nutritive value of rumen micro-organisms in ruminants. 4. The limiting amino acids of microbial protein in growing sheep determined by a new approach. Br. J. Nutr. 52, 613620.

Tao, R.C., Asplund, J.M. \& Kappel, L.C., 1974. Response of nitrogen metabolism, plasma amino acids and insulin levels to various levels of methionine infusion in sheep. J. Nutr. 104, 1646-1656. 
Titgemeyer, E.C. \& Merchen, N.R., 1990. The effect of abomasal methionine supplementation on nitrogen retention of growing steers postruminally infused with casein or nonsulfur - containing amino acids. J. Anim. Sci. 68, 2075-2083.

Young, A.W., Schelling, G.T., Tucker, R.F. \& Mitchell, G.E., 1981. Plasma amino acid response to abomasal infusions of amino acids in sheep. J. Anim. Sci. 52, 1421-1429. 